\title{
Making "academic talk" explicit: Research directions for fostering classroom discourse skills in children from nonmainstream cultures
}

\section{Anne van Kleeck, Amy Louise Schwarz}

This article focuses on making "school talk," or classroom discourse, more explicit on two levels. One level involves making explicit for teachers both the nature of school talk, and the reasons why many children may come to school unfamiliar with the school talk register. Providing teachers with this awareness enables them, in turn, to make school talk explicit for their students by directly explaining the rules for engaging in this type of discourse to them. As tools for enhancing teacher awareness, this article clearly distinguishes the school talk and everyday social talk registers and provides information regarding the cultural variation in children learning to use school talk at home. The shortcomings of previous implicit approaches to teaching school talk are examined, and ways to make the rules for engaging in this register explicit for children are suggested.

\section{Background}

Language in the classroom involves both social talk and, as children progress through the school years, increasing levels of academic talk. Academic talk generally differs in a number of ways from everyday social discourse. To be successful in school, children need to be adept with academic talk, regardless of how skilled they might be with social uses of language. Children of parents who are educated and identify with mainstream culture typically arrive at school, and even preschool, already having had a long apprenticeship in using classroom discourse. They can therefore transition to how talk is used in school rather seamlessly. For other children, however, classroom discourse may be unfamiliar, resulting in these children being less able to participate effectively in classroom interactions (e.g., Gee, 1996b; Heath, 1983; Michaels, 1981). This can negatively impact not only their ability to learn to read and to learn more generally (for a discussion see Wilkinson \& Silliman, 2000), but also their personal and social identities (Stables, 2003) and their teachers' perceptions of them (for a discussion see Reid, 2000). 
Theoretical Underpinnings

British sociologist and linguist Bernstein (e.g., 1970) discussed a similar distinction in language use decades ago in his sociolinguistic theory of language codes. He talked about an elaborated code in which meaning must be made more explicit in the language itself, because the speakers of the code cannot assume shared knowledge and understanding. This is similar in respects to what we refer to as academic talk. He also discussed a restricted code in which meaning is less explicit because of the shared background knowledge of the speakers. This pattern of language use reflects a communally-based culture and is similar to the everyday social talk described here.

Bernstein (e.g., 1970) noted that people who are identified as having middle socio-economic status (SES) use both codes. Because of their social mobility, they come in contact with many more people who do not share similar as much background knowledge with them, and hence they need to learn to use need to use an elaborated code. With generally less mobility, people who are identified as having a low SES will tend to have closely shared experiences and expectations with most others they come in contact with, which substantially lessens the need for elaboration in their communication. As such, children in these families would rarely find themselves in social circumstances in which they would need to be more explicit and elaborate in their language use. As we similarly argue here, Bernstein considered working-class children's lack of facility with the elaborated code to provide a partial explanation for their poorer academic performance in language-based subjects, which require an elaborated code.

Although Bernstein has been criticized on grounds that he considered working-class people somehow deficient (he did not), or because his writing was too dense and difficult (e.g., Sadovnik, 2001), his work has always aimed to "prevent the wastage of working-class educational potential” (Bernstein, 1961, p.308). Half a century later, we still need to meet this goal. This article reframes this issue away from the class distinctions of language use by grounding the issue in the dis-course registers children need to succeed academically.

\section{Relationship to and Importance of Academic Talk for Reading}

Facility with academic talk or classroom discourse has also long been regarded as an important foundation for literacy achievement (e.g., Michaels, 1981; Wilkinson \& Silliman, 2000). Academic talk in school shares more in common with written language than it does with spoken language used in everyday social contexts. In discussing Aboriginal children in Australia, Simpson and Clancy note that "before these learners can become adept with school literacy they need an understanding of how oral language works in the classroom" (p. 1, 2001). The same can be said for many children from nonmainstream culture (NMC) in Western schooling environments worldwide. However, it should be noted that using the term "literacy" in relation to academic talk is perhaps too broad. We need to 
consider decoding and comprehension separately. Classroom discourse skills provide foundations for reading comprehension (see Nystrand, 2006 for a review of the literature), whereas decoding skills are supported by letter knowledge and phonological awareness (see van Kleeck, 2007, June, for a model that separates the foundations for these two dimensions of later literacy).

For fourth grade children in the U. S., there are longstanding and often large achievement gaps in reading comprehension for children from linguistically and/or culturally diverse backgrounds (who are very over-represented in low-income groups) compared to their peers in mainstream culture (MC) (National Center for Education Statistics, 2009). Because such gaps are in place in preschool and kindergarten and persist throughout the school years (e.g., Princiotta, Flanagan, \& Germino Hausken, 2006; Whitehurst \& Fischel, 2000; Whitehurst \& Lonigan, 2001), efforts to close them need to begin during the preschool years. We suggest that one important research direction is to design interventions that will help teachers foster competence with the academic talk register in children from NMC backgrounds, thereby providing them with one important foundation for later reading comprehension.

\section{Academic Talk Research: Terminology and Focus}

There has been a long history of research aimed at understanding academic talk, although different terminology has been used, such as classroom (or literate) discourse, language, or talk (e.g., Bloome, Carter, Christian, \& Madrid, 2008; Cazden, 1986, 2001; Kutz, 1997; Macbeth, 2003; Marton \& Tsui, 2004; Mehan, 1979; Rex \& Schiller, 2009; Rymes, 2009; Vernon-Feagans, 1966; Wells, 1999). The vast majority of this work has focused on children in kindergarten and above, with a much smaller body of work looking at preschool classrooms (e.g., Kantor, Green, Bradley, \& Lin, 1992; Kleifgen, 1990; Kondyli \& Lykou, 2008; Yifat \& Zadunaisky-Ehrlich, 2008).

Researchers and theorists have been interested in how such talk unfolds using tools for studying naturally occurring discourse or discourse analysis (an early example is found in Mehan, 1979), how it reflects and perpetuates asymmetries of power in society using the tools of critical theory (e.g., Gee, 1996a; Young, 1992), and how this pattern of discourse might be unfamiliar to children from NMC backgrounds as they transition from home to school (e.g., Gee, 1996b; Heath, 1983; Michaels, 1981).

\section{Making Academic Talk More Explicit}

Currently, in research, assessments, and preschool curricula, oral language skill is typically considered as a unitary skill, albeit one that is comprised of various subdomains, such as vocabulary, morpho-syntax, and phonology. We will likely make more progress in appropriately fostering oral language foundations for la- 
ter literacy if we think of them as falling into two separable registers - social talk and academic talk - and focus our efforts on ensuring children are familiar and comfortable with how talk is used during lessons in school. To highlight how this might be done, we first review two areas of research that focus on preschool classroom activities we believe important for fostering academic talk in preschoolers - sharing time and book sharing. We then explicitly distinguish social and academic talk, which we believe will be helpful for educating teachers about these different registers, so they in turn can consciously foster academic talk in young preschool children.

\section{Previous Research on Implicitly Fostering Academic Talk}

Two areas of research conducted in preschool classrooms are relevant to the issue of academic talk - research focused on sharing time and on book sharing. We review this research briefly in order to emphasize the ways we believe we could more fruitfully foster academic talk in children from NMC backgrounds in future intervention research. With sharing time research, the goal has been to explore how teachers implicitly socialize children to use academic talk. With book sharing research, the goal has been to share books with children to enhance their oral language skills. The book sharing research then has not specifically considered how book sharing fosters the academic talk register (but see van Kleeck, 2007, for one discussion).

\section{Sharing time as a vehicle for co-constructing academic talk.}

Sharing time has been a focus of most of the research on academic talk with preschoolers, as well as with older children. Sharing time is a school activity in which children individually discuss personal experiences with the entire class via oral narratives that are typically guided by their teacher's interspersed questions and comments. It is also known as circle time, rug time, show and tell, and news time (Barletta, 2008). The teacher contributes questions and comments to a child's sharing time narrative in order to "recontextualize" (Cazden, 2001) the child's more social talk into school discourse. This type of indirect process typically is one of the few opportunities a child has to learn how to engage in academic talk if he or she did not arrive at school already familiar with this pattern of language use. It is interesting that this is done during sharing time, since talk about personal issues would more appropriately be conveyed in a social talk manner, and not in academic talk. Perhaps sharing time is conceived of as a bridge between social talk and academic talk. But, as we see below, it may not be very effective for the children who most need such guidance.

In a recent synthesis of this sharing time research conducted with children in grades kindergarten through grade seven, Barletta (2008) discussed the difficulties teachers have in re-contextualizing the oral narratives of African American (AA) children, mostly from poor or working-class families. These children struggle not only because they are less familiar with the academic talk register before 
arriving at school, but also because they come from cultures that produce oral narratives according to different rules than those valued in Western school environments (see Westby, 1994, for a synthesis of this research). A number of studies reviewed by Barletta (e.g., Hyon \& Sulzby, 1994) show that AA children sometimes produce topic-associated or episodic narratives during sharing time (organized around loosely linked topic with shifts in key characters, time, and location making them nonlinear), rather than the topic-centered narratives (tightly organized on a single identifiable topic) typical of U.S. mainstream and school culture. This was true of $33 \%$ of the sharing time stories produced by 48 AA kindergartners in the Hyon and Sulzby study.

In conveying a point made by Michaels (1984), Barletta (2008) notes that, "in order to be considered competent, children must conform to the teacher's implicit expectations as to how information should be organized and presented" (p. 3). When a child does not conform to these expectations, as when they use a topic associating style, the teacher may view the child's story as incoherent, and as a result, the teacher may give less attention and instructional time to the child (Gee, 1985). The teacher might admonish the child to talk about "important things" or "one thing only" (Michaels, 1981), and consider the child's narrative to be "uncommunicative and unacceptable" (Barletta, 2008, p. 16). The teacher's attempts to collaborate with a child who produces a topic-association narrative often fail because the teacher tends to interrupt the child mid-sentence to ask incongruous or mistimed questions (Barletta, 2008). We believe that these kinds of findings would undoubtedly also applies to preschoolers.

Without having a conscious awareness of either the specific dimensions of academic talk or the various ways in which personal narratives can be constructed by members of different cultural groups, teachers' use of sharing time to foster academic talk with children who do not use a topic-centered personal narrative style may have the kinds of unintended negative consequences just discussed. In future research we suggest researchers test the approach of directly telling children that the goal is to talk about their personal item or story, but to do so in an academic talk manner. That is, we could let them in on this particular rule that is part of the hidden curriculum - that providing personal information is sanctioned in school only if it is offered in the service of more general, theoretical knowledge. As such, the teacher might say, "When you talk about your special rock in school, you may quickly tell us why it is special to you, but then we also want to talk together about what kind of rock it is, and what that kind of rock is like. That way, we can use your special rock to learn about lots of rocks. I'll help you by asking you some questions as you tell us about your special rock."

\section{Book sharing in preschool: A prime opportunity to teach academic talk.}

In another body of research relevant to academic talk, the starting point for considering teacher-child interactions is often the text of a story book that is read to a group of children (although other classroom contexts have occasionally also 
been studied, e.g., Dickinson \& Smith 1991; Gest, Holland-Coviello, Welsh, Eicher-Catt, \& Gill, 2006; Massey, Pence, Justice, \& Bowles, 2008). Researchers have been primarily interested in the ways in which a parent or teacher encourages children to verbally participate in discussions of stories, both by prompting their participation and "scaffolding" (Wood, Brunner \& Ross, 1976) and reinforcing their responses. They have also been interested in teachers' use of more challenging level questions. Although children's participation in book sharing has not been considered as practice in academic talk, it clearly is, and it would undoubtedly be helpful to frame it as such so that the rules of this discourse can once again be made explicit for the children.

Attempting to get children to participate more in discussions about the book is motivated by intervention research showing that such interactive book sharing will enhance children's language development (for meta-analyses of this intervention research see Mol, Bus, \& de Jong, 2009; Mol, Bus, de Jong, \& Smeets, 2008; National Early Literacy Panel, 2008). The child language outcomes in this research have been either vocabulary or more general oral language development, with no efforts to differentiate between social and academic registers. Hence, what is not acknowledged is how discussions during book sharing in middleclass, educated families and in some preschools directly mirror academic talk adults ask children to engage in verbal display of what they already know or of their thinking as they use their language to build new knowledge. As such, book sharing provides an excellent opportunity to foster academic talk in children not already familiar with this type of talk. However, to use book sharing to foster academic talk, preschool teachers need to know how to develop children's use of academic talk during this activity. More specific ideas on how to do this in future intervention research are provided next.

We suggest that preschool teachers directly tell children who are less familiar with academic talk (repeatedly and in a variety of ways) how it works. The gist of such a conversation might be as follows: "Because we are in school, I'm going to ask you and the other children questions I already know the answer to. If you know the answer, I want you to raise your hand, and tell me the answer. In school, tell me answers I already know so I can see if you know the answer. That helps me know if I'm doing a good job teaching you. If you don't know the answer, that's okay, too. Maybe another child or I will give the answer."

For higher-level questions, the teacher might directly explain (repeatedly and in a variety of ways) to the children: "Sometimes, you might not know the answer to questions I ask, but you can think about what the answer might be, and you can tell us what you are thinking. "Teachers can also model this process, and say something like, "I wonder who this book is going to be about?' I haven't read this book before, so I don't know for sure who it is about. But I can use hints from the cover to guess who the book might be about. There is a picture of a bear and a bird on the cover, so maybe the book is about the bird or the bear, or maybe about both. But, I'd have to read the book to find out if I made a good guess or not." 
When a child responds, the teacher could also follow-up with both an evaluation of the correctness of the response and an explanation of the discourse rule the child was correctly following. For example, looking at the cover of Mooncake (Asch, 1987), the teacher might ask, "What color is the bear?" If one child correctly answered and said, "Brown," the teacher might then say, "That's right, the bear is brown. And I like the way you answered my question, even though you probably thought I already knew the bear was brown. That's how we talk in school." If no child is able to respond, the teacher could simply answer the question her or himself.

Interestingly, the technique of having the adult answer his or her own questions is one of the many recommended strategies taught to adults in the widelyresearched preschool book sharing intervention developed by Whitehurst and his colleague called dialogic reading (see Zevenbergen \& Whitehurst, 2003, for a summary of this research). Dialogic reading trains adults to prompt children with questions, and praise and expand their contributions to discussions about a book in order to enhance their oral language development. In studies in which dialogic reading was taught to adults in daycare centers, the effectiveness of the intervention in enhancing children's language skills was mediated by how well the participants were able to adhere to the book sharing strategies they were taught - children made greater gains when adults implemented the intervention consistently (Lonigan \& Whitehurst, 1998; Whitehurst et al., 1994). The same appears to be true in preschools. A meta-analysis of preschool teachers' interactive book sharing reported that studies with higher treatment fidelity had higher effect-sizes for child language outcomes (Mol et al., 2009).

Van Kleeck (2006a) suggested that, in cases where teachers are unable to adhere to the treatment they are trained to give, it may be due to a mismatch between the strategies taught in dialogic reading and the cultural values and beliefs of many of those teachers. Indeed, in 2008 in the U.S., 44\% of preschool teachers and daycare workers had a high school degree or less (U. S. Bureau of Labor Statistics, retrieved from http://www.bls.gov/oco/cg/cgs032.htm). Since many are not from well-educated, middle-class backgrounds, they would be less likely to be adept at the academic talk register themselves, and therefore would not be able to effectively teach it.

For dialogic reading to be more faithfully implemented, in future research teachers need to recognize book sharing as a context for fostering academic talk, and not just for oral language in general. They would then be aware that some children may not have experience with many aspects of academic talk, so could employ the kinds of strategies suggested throughout this article to support the children's participation. 


\section{Helping Teachers Distinguish Between Social Talk and Academic Talk}

In this section, we distinguish between social talk and academic talk by discussing how each register tends to differ along a number of dimensions. Being aware of these differences should also help teachers teach academic talk to children, although this is also an idea that should be tested empirically in intervention research in which teachers are explicitly taught about these differences. The dimensions along which social and academic talk differ concern why we talk, how we talk, and what we talk about (see van Kleeck, 2006a).

Please note that we are not suggesting that children be taught about the differences between everyday social talk and academic talk outside of being engaged in a meaningful activity (such as discussion during book sharing) in which academic talk is required. Such a decontextualized treatment of academic talk would require metacognitive skills that are generally beyond the cognitive level of preschoolers (see van Kleeck, 1994, for discussion). Increasing teachers' awareness of these differences, however, might help increase their own modeling of academic talk and their ability to elicit it from children. Large-scale research in the U.S. clearly indicates that quality of instructional interactions is positively associated with children's language and academic outcomes, whereas infrastructure variables (e. g., levels of teacher training, class size) are not (Mashburn et al., 2008). Furthermore, the lowest quality is found in classrooms serving low-income children (LoCasale-Crouch et al., 2007; Pianta et al., 2005).

\section{Why we talk.}

Why we talk both overlaps and differs in and out of school. As we go about our daily living in and out of school, we use social talk to get information, to get things done, and to maintain relationships with other people. However, children's talk when the teacher is focused on teaching consist primarily of the children's verbal display that is used to show what they already know or to show the thinking process they are going through as they build new knowledge.

\section{Verbal display.}

Children are regularly required to verbally display their acquired knowledge in the classroom context (e.g., Reid, 2000), often when a teacher asks questions to which the teacher already knows the answer. So, for example, during "calendar time," the teacher asks, "What day is it today?" and "Is it sunny or raining today?" The important aspect of these questions from a cultural perspective is that the child would typically be aware that the teacher already knows the answer. The teacher is requesting that the children provide information the teacher already has. This stands in stark contrast to how questions are used in everyday social talk, which is as a genuine request for information one does not already have. These kinds of questions have been referred to by different authors as "test questions" (e.g., Nystrand, Wu, Gamoran, Zeiser, \& Long, 2003), "known information 
questions" (e.g., Mehan, 1979), or "questions with known answers" (e.g., Macbeth, 2003). They presumably let the teacher know what a child knows, and as such function as a kind of spontaneous test, rather than as a genuine request for information. They also allow children to have success in classroom participation when they possess the information that is being requested.

Children from MC backgrounds are typically exposed to these kinds of questions for several months before they even begin to talk. So, during book sharing with an infant, the adult might both ask and answer questions, as in, "Oh look (pointing to a bunny in the book), what's that? [pause] That's a bunny!" In NMC groups in the U.S., using verbal display to tell someone what you already know may not be part of children's socialization. Heath notes that the working-class African American children in her study were rarely asked this type of question, and when they were, it was often to chastise them (Heath, 1983). Among Mexican Americans, Valdés notes that such known-information questions may be reserved for teasing children (Valdés, 1996). And finally, Harris finds that Native American children may be socialized to not respond to these known-information questions (Harris, 1998).

\section{Building knowledge.}

Using talk in the classrooms to build knowledge involves going beyond information that is already known by the child. It is important to note that knowledge being built in school is not usually the practical everyday kind associated with doing concrete things in the world competently, but is a more theoretical knowledge (term used by Wells, 1999) that is detached from practical doing and hence more context-independent (what many have called de-contextualized). In Western culture schools, children learn about the world in general terms. For example, they learn that bears are a type of animal and more specifically a type of mammal, that there are subtypes of them, that different ones may have different habitats and hence different foods and shelters and so forth, that some of them might be endangered. During a classroom lesson, there is far less interest in the personal story about the specific bear a child saw hiking with her or his family.

Looking just at the book sharing activity in U.S. families who identify with mainstream culture, we see that as children develop across the years before formal schooling, parents' discussions prompt their children to think about information in books at increasingly higher levels (e.g., De Temple \& Snow, 1996; Goodsitt, Raitan, \& Perlmutter, 1988; Heath, 1982, 1983; Martin, 1998; Ninio \& Bruner, 1978; Sigel \& McGillicuddy-Delisi, 1984; Snow \& Ninio, 1986; Sorsby \& Martlew, 1991; van Kleeck, 1998; van Kleeck \& Beckley-McCall, 2002; van Kleeck, Gillam, Hamilton, \& McGrath, 1997; Wheeler, 1983). For example, parents will over time make more comments and ask the child more questions that involve such things as summarizing, explaining, evaluating, giving factual information, defining, comparing and contrasting, and anticipating/predicting future events. In this way, these preschoolers are also exposed to "building know- 
ledge" questions. And here again, as with "display acquired knowledge" questions, the adult will not only ask such questions, but will also answer them if the child is unable, or perhaps unwilling, to do so. Van Kleeck (2006b) summarizes research from her own lab showing that, on average, approximately $40 \%$ of middle-class U.S. parents' talk about storybooks shared with 3;6 (years; months) to $4 ; 1$ year olds is at more cognitively challenging levels, and this percentage is even higher $(50 \%)$ with expository or information books (Price, van Kleeck, \& Huberty, 2009). That adds up to a great deal of practice with these types of questions and discussion for children from mainstream culture backgrounds.

Janes and Kermani (2001) provide a dramatic example of the potential cultural differences in the tendency to use "build knowledge" questions with preschoolers. They reported that the Latino immigrant families in their book sharing intervention study did not expect preschool-aged children "to think out loud or talk about stories" (p. 464). Instead, the children were expected to "listen and observe" (p. 464). Van Kleeck (2006b) summarizes research indicating less use of such higher level questions during book sharing by parents in the U.S. from other nonmainstream cultures, as well.

For children who have not been socialized to do so at home, we should consciously begin their apprenticeship in answering "building knowledge" questions in preschool. When a child does not answer such a question, the teacher could provide a possible answer, introducing it with phrases such as "I wonder if," or "Maybe he's thinking." In this way, the teacher is "showing" the child the thinking her or she is engaging in to answer the question. The use of "maybe" or "I wonder" implies that the adult may not be sure she or he is absolutely correct. From this the child learns that it's okay to not be entirely sure in answering "thinking" or "building knowledge" questions. The adult might demonstrate that you can use logic or past experience to speculate, and sometimes that's all you can do.

Additionally, to facilitate children's ability to bring background knowledge to bear in answering both types of verbal display questions, it would likely be helpful to adapt books to the background knowledge and interests of the children and their families. This may involve creating books in collaboration with families, as was done effectively in the Janes and Kermani study (2001) after efforts to train low-income Latino parents (most of whom were recent immigrants) to ask both types of verbal display questions failed when commercially available texts were used.

\section{How we talk.}

Regarding how we talk, social talk generally employs simpler vocabulary and syntax, and vernacular words and expressions are common. Shared background knowledge can be assumed (so that not everything has to be explicitly stated), speakers can interrupt to seek clarification, and turn taking tends to be relatively balanced. Academic talk abounds in rare and more technical vocabulary. Speakers are not to assume that their listeners already know about a subject. Instead, 
in their talk, they are to be specific, explicit, provide necessary detail, and carefully and logically explain. These requirements often result in more complex syntax, since more information must be expressed linguistically. In most classrooms, teachers do most of the talking during classroom lessons, so there is both less balance in turn taking, and less frequent opportunities for listeners to seek clarification.

\section{What we talk about.}

What gets talked about also tends to differ social and academic talk. Socially, our talk typically centers on things that are personally important and/or immediately relevant to us. So, we tend to hear more about particular people, objects, and events as personal activities, experiences, plans, and opinions are conveyed. In school, topics do not tend to be immediately relevant. Because the goal is to develop theoretical knowledge, talk is used to describe, explain, and think in general ways about general things and events - not personal ones. How do children learn these distinctive reasons why one talks, how one talks, and what one talks about in school if they do not come to school already well-versed in this register? In this article, we have outlined potential ways to do this, and present these ideas as ways to focus future research. We believe we need to more specifically aim our efforts at fostering language skills in preschoolers to those particular patterns of language use important for success in the classroom.

\section{Conclusions}

Preschool curricula currently abound with efforts at fostering children's general oral language skills and foundations for later literacy. In 2002, the U.S. Institute of Education Sciences (IES) began the Preschool Curriculum Evaluation Research (PCER) initiative to conduct rigorous efficacy evaluations using randomized control trials of numerous available preschool curricula with low-income preschoolers (results are reported in Preschool Curriculum Evaluation Research Consortium, 2008). The control conditions were the existing curricula in the schools in which the studies were conducted. Thirteen of the 14 curricula evaluated focused on language and literacy skills, and for 12 of those, the prekindergarten effect sizes for the two standardized child language outcome measures used in all of the studies (one omnibus language measure and one receptive vocabulary measure) were small and nonsignificant (ranging from -.38 to .23). These are not impressive results for current attempts to foster early language and literacy skills, and other research indicates that preschools for low-income children in general often do a poor job of preparing them for later literacy (e.g., Whitehurst \& Massetti, 2004).

There are likely two interrelated reasons that might at least partly account for the current poor performance of U.S. preschools in fostering language and lite- 
racy skills in preschoolers who are most at risk for later academic difficulties. On one hand, language skills are not currently approached as consisting of two fairly distinct registers - social talk and academic talk - and as such the various dimensions of academic talk are not directly or consciously fostered, even though these are precisely the dimensions of language that undergird later reading comprehension. On the other hand, the standardized tests used to determine preschoolers' progress in oral language skills are, at least in part, tests of "academic talk." That is, in language and other standardized testing, adults who presumably know the answers themselves ask children to display their knowledge. Performing well on them would likely be easier for children who are quite familiar and comfortable with such displays of knowledge. So, although academic talk isn't being taught (not systematically and consistently with all children, at any rate), it appears to be at least part of what is being measured.

The failure of preschools for low-income children to markedly enhance critical readiness skills is addressed differently from a critical theory perspective. For example, Gee (1996a) suggests that the goals of education are to create two classes of citizens. He discussed the differences in educational goals for low-income versus higher income students as being the difference between the literacy of deference and the literacy of critical thinking. Schooling goals for low-income children include "docility, discipline, time-management, honesty and respect" (p. 34), while those for higher SES children include "critical thinking, discursive thought, and writing" skills (p. 34). Ensuring that preschoolers are familiar and comfortable with the ways in which language is used in school is an important tool for countering these potential types of inequities.

\section{References}

Asch, F. (1987). Mooncake. New York: Scholastic.

Barletta, L. M. (2008). Teacher's differential of culturally and linguistically diverse students during sharing time. Colorado Research in Linguistics, 21(1 - 21).

Bernstein, B. (1961). Social class and linguisic development: A theory of social learning. In: A. H. Halsey, J. Floud, \& C. A. Anderson (Eds.), Education, economy and society, p. 288314. New York, Free Press.

Bernstein, B. B. (1970). A sociolinguistic approach to socialization: With some reference to educability. In F. Williams (Ed.), Langauge and poverty (pp. 25-61). Chicago: Rand McNally.

Bloome, D., Carter, S. P., Christian, B. M., \& Madrid, S. (2008). On discourse analysis in classrooms: Approaches to language and literacy research. New York: Teachers College Press.

Cazden, C. B. (1986). Classroom discourse. In M. Wittrock (Ed.), The handbook of research on teaching, Vol. S (pp. 432 - 463). New York: Macmillan.

Cazden, C. B. (2001). Classroom discourse: The language of teaching and learning (2nd ed.). Portsmouth, NH: Heinemann.

De Temple, J. M., \& Snow, C. E. (1996). Styles of parent-child book-reading as related to mothers' views of literacy and children's literacy outcomes. In J. Shimron (Ed.), Literacy and Education: Essays in Honor of Dina Feitelson (pp. 63-84). Cresskill, NJ: Hampton Press. 
Dickinson, D. K., \& Smith , M. W. (1991). Preschool talk: Patterns of teacher-child interaction in early childhood classrooms. Journal of Research in Childhood Education, 6(1), 20 - 29.

Gee, J. P. (1985). The narrativization of experience in the oral style. Jounral of Education, $167(1), 9-35$.

Gee, J. P. (1996a). Literacy and the literacy myth: From Plato to Freire. Social linguistics and literacties: Ideology in discourses (2nd ed., pp. 22-45). New York: Routledge Falmer, Taylor $\&$ Francis, Inc.

Gee, J. P. (1996b). Social linguistics and literacies: Ideology in discourses (2nd ed.). New York: RoutledgeFalmer, Taylor \& Francis, Inc.

Gest, S. D., Holland-Coviello, R., Welsh, J. A., Eicher-Catt, D. L., \& Gill, S. (2006). Language development subcontexts in Head Start classrooms: Distinctive patterns of teacher talk during free play, mealtime, and book reading. Early Education \& Development, 17(2), 340 - 360.

Goodsitt, J., Raitan, J. G., \& Perlmutter, M. (1988). Interaction between mothers and preschool children when reading a novel and familiar book. International Journal of Behavioral Development, 11, 489-505.

Harris, G. (1998). American Indian cultures: A lesson in diversity. In D. Battle (Ed.), Communication disorders in multicultural populations (2nd ed., pp. 117-156). Stoneham, MA: Heinemann Publishing.

Heath, S. B. (1982). What no bedtime story means: Narrative skills at home and school. Language in Society, 11, 49-76.

Heath, S. B. (1983). Ways with words: Language, life, and work in communities and classrooms. New York: Cambridge University Press.

Hyon, S., \& Sulzby, E. (1994). African American kindergartners' spoken narratives: Topic associating and topic centered styles. Linguistics and Education, 6, $121-152$.

Janes, H., \& Kermani, H. (2001). Caregivers story reading to young children in family literacy programs: Pleasure of punishment. Journal of Adolescent and Adult Literacy, 44, 458-446.

Kantor, R., Green, J., Bradley, M., \& Lin, L. (1992). The construction of schooled discoured repertoires" An interactional sociolinguistic perspective on learning to talk in preschool. Linguistics and Education, 4(131 - 172).

Kleifgen, J. A. (1990). Prekindergarten children's second discourse learning. Discourse Processes, 13, $225-242$.

Kondyli, M., \& Lykou, C. (2008). Defining and classfying in classroom discourse: Some evidence from Greek pre-school education. Language and Education, 22(6), 331 - 344.

Kutz, E. (1997). Language and Literacy: Studying discourse in communities and classrooms. Portsmouth, NH: Boynton/Cook.

LoCasale-Crouch, J., Konold, T., Pianta, R. C., Howes, C., Burchinal, M., Bryant, D., et al. (2007). Observed classroom quality profiles in state-funded pre-kindergarten programs and associations with teacher, program, and classroom characteristics. Early Childhood Research Quarterly, 22, 3-17.

Locke, J. L. (2008). The trait of human language: lessons from the canal boat children of England. Biology and Philosophy, 23, 347 - 361.

Lonigan, C. J., \& Whitehurst, G. (1998). Relative efficacy of parent and teacher involvement in shared reading intervention for preschool children from low-income backgrounds. Early Childhood Research Quarterly, 13, 263-290.

Macbeth, D. (2003). Hugh Mehan's "Learning Lessons" reconsidered: On the differences between the naturalistic and critical analysis of classroom discourse. American Educational Research Journal, 40(1), 239 - 280.

Martin, L. E. (1998). Early book reading: How mothers deviate from printed text for young children. Reading Research and Instruction, 37(2), 137-160.

Marton, F., \& Tsui, A. B. (2004). Classroom discourse and the space of learning. Mahwah, NJ: Lawrence Erlbaum Associates. 
Mashburn, A. J., Pianta, R. C., Hamre, B. K., Downer, J. T., Barbarin, O. A., Donna Bryant, et al. (2008). Measures of classroom quality in prekindergarten and children's development of academic, language, and social skills. Child Development 3, 732-749.

Massey, S. L., Pence, K. L., Justice, L. M., \& Bowles, R. P. (2008). Educators' use of cognitively challenging questions in economically disadvantaged preschool classroom contexts. . Early Education \& Development, 19(2), 340 - 360.

Mehan, H. (1979). Learning lessons. Cambridge, MA: Harvard University Press.

Mercer, N. (1995). The guided construction of knowledge. Bristol, UK: Multilingual Matters.

Michaels, S. (1981). "Sharing time": Children's narrative styles and differential acces to literacy. Language in Society, 10, 423 - 442.

Michaels, S. (1983). The role of adult assistance in children's acquisition of literate discourse strategies. The Volta Review, 85(5), 72 - 86.

Michaels, S. (1984). Listening and responding: Hearing the logic in children's classroom narratives. Theory into Practice, 23(3), 218 - 224.

Mol, S. E., Bus, A. G., \& de Jong, M. T. (2009). Interactive book reading in early education: A tool to stimulate print knowledge as well as oral language. Review of Educational Research, 79(2), $979-1007$.

Mol, S. E., Bus, A. G., de Jong, M. T., \& Smeets, D. J. H. (2008). Added value of dialogic parent-child book readings: A meta-analysis. Early Education and Development, 19(1), 7 - 26.

National Center for Education Statistics. (2009). The Nation's Report Card: Reading 2009 (NCES 2010-458). Washington, D.C.: Institute of Education Sciences, U.S. Department of Education.

National Early Literacy Panel. (2008). Developing early literacy: Report of the National Early Literacy Panel. Washington, DC.

Ninio, A., \& Bruner, J. (1978). The achievement and antecedents of labeling. Journal of Child Language, 5, 1-15.

Nystrand, M. (2006). Research on the role of classroom discourse as it affects reading comprehension. Research in the Teaching of English, 40, 392 - 412.

Nystrand, M., Wu, L. L., Gamoran, A., Zeiser, S., \& Long, D. A. (2003). Questions in time: Investigating the structure and dynamics of unfolding classroom discourse. Discourse Processes, 35(2), 135 - 198.

Pianta, R. C., Howes, C., Burchinal, M., Bryant, D., Clifford, R., Early, D. M., et al. (2005). Features of pre-kindergarten programs, classrooms, and teachers: Do they predict observed classroom quality and child-teacher interactions? Applied Developmental Science, 9(3), 144-159.

Preschool Curriculum Evaluation Research Consortium. (2008). Effects of Preschool Curriculum Programs on School Readiness (NCER 2008-2009). Washington, D.C.: National Center for Education Research, Institute of Education Sciences, U.S. Department of Education.

Price, L. H., van Kleeck, A., \& Huberty, C. J. (2009). Talk during book sharing between parents and preschool children: A Comparison between storybook and expository book conditions. Reading Research Quarterly, 44(2), 171 - 194.

Princiotta, D., Flanagan, K. D., \& Germino Hausken, E. (2006). Fifth grade: Findings from the fifth-grade follow-up of the Early Childhood Longitudinal Study, Kindergarten class of 1998-99 (ECLS-K).

Reid, D. K. (2000). Discourse in classrooms. In K. Fahey \& D. K. Reid (Eds.), Language development, differences, and disorders (pp. 3-38). Austin, TX: Pro-Ed.

Rex, L. A., \& Schiller, L. (2009). Using discourse analysis to improve classroom interaction. New York: Routledge.

Rymes, B. (2009). Classroom discourse analysis: A tool for critical reflection. Cresskill, NJ Hampton Press.

Sadovnik, A. R. (2001). Basil Bernstein (1924 - 2000). Prospects: The Quarterly Review of Comparative Education, 31(4), 687-703. 
Scollon, R., \& Scollon, S. (1981). Narrative, literacy, and face in interethnic communication. Norwood, NJ: Ablex.

Sigel, I. E., \& McGillicuddy-Delisi, A. V. (1984). Parents as teachers of their children: A distancing behavior model. In A. D. Pellegrini \& T. D. Yawkey (Eds.), The development of oral and written language in social contexts (pp. 71-91). Norwood, NJ: Ablex.

Simpson, L., \& Clancy, S. (2001). Developing classroom discourse with young Aboriginal literacy learners. Australian Jounral of Teacher Education, 26(1), 1 - 10.

Snow, C. E., \& Ninio, A. (1986). The contracts of literacy: What children learn from learning to read books. In W. H. Teale \& E. Sulzby (Eds.), Emergent literacy: Writing and reading (pp. 116-137). Norwood, NJ: Ablex.

Sorsby, A. J., \& Martlew, M. (1991). Representational demands in mothers' talk to preschool children in two contexts: Picture book reading and a modeling task. Journal of Child Language, 18, 373-395.

Stables, A. (2003). Learning, identity and classroom dialogue. Journal of Educational Enquiry, $4(1), 1-18$.

Stubbs, M. (1976). Language, schools and classrooms. London: Methuen and Co, Ltd.

Valdés, G. (1996). Con respeto: Bridging the distances between culturally diverse families and schools. New York: Teachers College Press.

van Kleeck, A. (1994). Metalinguistic development. In G. Wallach \& K. Butler (Eds.), Language learning disabilities in school-age children and adolescents: Some principles and applications (pp. 53-98). New York: Macmillan.

van Kleeck, A. (1998). Preliteracy domains and stages: Laying the foundations for beginning reading. Journal of Children's Communication Development, 20, 33-51.

van Kleeck, A. (2006a). Cultural issues in promoting interactive book sharing in the families of preschoolers. In A. van Kleeck (Ed.), Sharing books and stories to promote language and literacy (pp. 179-230). San Diego: Plural Publishing.

van Kleeck, A. (2006b). Fostering inferential language during book sharing with preschoolers: A foundation for later text comprehension strategies. In A. van Kleeck (Ed.), Sharing books and stories to promote language and literacy (pp. 269-318). San Diego: Plural Publishing.

van Kleeck, A. (2007). Home talk and school talk: Helping teachers recognize cultural mismatches. Paper presented at the ASHA Schools Conference.

van Kleeck, A. (2007, June). Preschool foundations for reading comprehension: Making the case for the critical Importance of inferencing. Paper presented at the Symposium for Research in Child Language Disorders.

van Kleeck, A., \& Beckley-McCall, A. (2002). A comparison of mothers' individual and simultaneous book sharing with preschool siblings: An exploratory study of five families. American Journal of Speech-Language Pathology, 11(2), 175-189.

van Kleeck, A., Gillam, R., Hamilton, L., \& McGrath, C. (1997). The relationship between middle-class parents' book-sharing discussion and their preschoolers' abstract language development. Journal of Speech-Language-Hearing Research, 40, 1261-1271.

Vernon-Feagans, L. (1966). Children's talk in communities \& classrooms. Cambridge, MA: Blackwell Publishers.

Wells, G. (1999). Dialogic inquiry: Toward a sociocultural practice and theory of education. Cambridge: Cambridge University Press.

Westby, C. E. (1994). The effects of culture on genre, structure, and style of oral and written texts. In G. Wallach \& K. Butler (Eds.), Language learning disabilities in school-age children and adolescents (pp. 180-218). New York: Merrill.

Wheeler, M. P. (1983). Context-related age changes in mothers' speech: Joint book reading. Journal of Child Language, 10, 259-263.

Whitehurst, G., Arnold, D. S., Epstein, J. N., Angell, A. L., Smith, M., \& Fischel, J. E. (1994). A picture book reading intervention in day care and home for children from low- 
income families. Developmental Psychology, 30, 679-689.

Whitehurst, G., \& Fischel, J. (2000). A developmental model of reading and language impairments arising in conditions of economic poverty. In D. Bishop \& L. Leonard (Eds.), Speech and language impairment: From theory to practice (pp. 53-71). East Sussex: Psychology Press.

Whitehurst, G., \& Lonigan, C. (2001). Emergent literacy: Development from prereaders to readers. In S. B. Neuman \& D. K. Dickinson (Eds.), Handbook of Early Literacy Development (pp. 11-29). New York: Guilford Publications.

Whitehurst, G., \& Massetti, G. M. (2004). How well does Head Start prepare children to learn and read? In E. Zigler \& S. J. Styfco (Eds.), The Head Start Debates (pp. 251-262). Baltimore: Paul H. Brookes.

Wilkinson, L. C., \& Silliman, E. R. (2000). Classroom language and literacy learning. In M. L. Kamil, P. D. Mosenthal, P. D. Pearson \& R. Barr (Eds.), Handbook of reading research (Vol. III) (pp. 337 - 360). Mahwah, NJ: Erlbaum.

Wood, D., Brunner, J.S., \& Ross, G. (1979). The role of tutoring in problem solving. Journal of Psychology an Psychiatry. 17, 89-100.

Yifat, R., \& Zadunaisky-Ehrlich, S. (2008). Teachers' talk in preschools during circle time: The case of revoicing Journal of Research in Childhood Education, 23(2), 211 - 226.

Young, R. (1992). Critical theory and classroom talk. Clevedon, UK: Multilingual Matters.

Zevenbergen, A., \& Whitehurst, G. (2003). Dialogic reading: A shared picture book reading intervention for preschoolers. In A. van Kleeck, S. A. Stahl \& E. Bauer (Eds.), On reading to children: Parents and teachers (pp. 177-200). Mahwah, NJ: Lawrence Erlbaum Associates.

Key words: preschool, classroom discourse, explicit instruction 


\section{Die Unterrichtssprache als expliziter Lerngegenstand: Forschungsperspektiven zur Förderung unterrichtssprach- licher Fähigkeiten von bildungsbenachteiligten Kindern}

\section{Zusammenfassung}

Der Beitrag befasst sich auf zwei Ebenen mit der Forderung, die Unterrichtssprache bzw. den Klassenzimmer-Diskurs als Lerngegenstand explizit zu vermitteln. Einerseits geht es darum, den Lehrpersonen bewusst zu machen, dass die Unterrichtssprache eine spezifisch ausgeforme Sprache ist, und dass viele Kinder beim Schuleintritt noch nicht über dieses sprachliche Register verfügen. Wenn sich die Lehrpersonen dieser Sachverhalte bewusst sind, können sie die Kinder unterstützen, indem sie die Regeln des Klassenzimmer-Diskurses explizit vermitteln. Im Hinblick auf diese Bewusstseinsbildung werden die Unterschiede der alltags- und unterrichtssprachlichen Register dargestellt und Hintergrundinformationen zu den unterschiedlichen familiären Bedingungen für den Erwerb der Unterrichtssprache gegeben. Andererseits werden auf der Ebene der konkreten Förderpraktiken die Probleme der bisherigen, impliziten Zugänge diskutiert und Formen der expliziten Vermittlung unterrichtssprachlicher Fähigkeiten vorgeschlagen.

Schlagworte: Vorschule, Unterrichtssprache, Sprachförderung, explizite Vermittlung

\section{Rendre la "langue scolaire» explicite: directions de recherche favorables au développement de compétences discursives en classe chez des enfants de cultures minoritaires}

\section{Résumé}

Cet article vise à rendre la "langue scolaire» ou le discours de la classe plus explicite à deux niveaux. Un premier niveau cherche à rendre explicite pour les enseignants la nature de la langue scolaire et les raisons pour lesquelles plusieurs enfants arrivent à l'école sans être familiarisés avec le registre du discours scolaire. En rendant les enseignants conscients de ce fait, ceux-ci peuvent, à leur tour, rendre le discours scolaire explicite pour leurs élèves en leur expliquant directement les règles qui leur permettent de s'engager dans ce type de discours. En proposant des outils pour l'enseignant, cet article distingue clairement le registre de la langue scolaire et celui du discours quotidien. Il aborde l'aspect de la variation culturelle lorsque les enfants apprennent la langue scolaire à la maison. Les résultats d'approches implicites existantes sont examinés et des pistes pour rendre ce registre explicite en classe sont suggérées.

Mots clés: Préscolaire, langue scolaire, enseignement explicite 


\section{Esplicitare il "linguaggio accademico": Indicazioni dalla ricerca per stimolare le competenze argomentative in aula di bambini appartenenti a culture non-mainstream}

\section{Riassunto}

Questo articolo mira a rendere più esplicito il linguaggio scolastico, o linguaggio accademico, su due livelli. Il primo riguarda l'esplicitazione per gli insegnanti della natura del linguaggio accademico e delle ragioni per cui molti bambini facciano il loro ingresso nella scuola senza conoscerlo. Rendere consapevoli gli insegnanti permette loro di rendere esplicito il linguaggio accademico per i loro allievi, spiegando apertamente le regole per usarlo. Come strumenti per aumentare la consapevolezza degli insegnanti, l'articolo distingue i registri sociali scolastico e quotidiano e presenta informazioni sulle variazioni culturali nell'apprendimento del linguaggio accademico relative al contesto familiare. Vengono esaminati gli svantaggi di un approccio implicito al linguaggio accademico, e vengono suggerite alcune modalità per rendere esplicito questo registro in classe.

Parole chiave: Scuola dell'infanzia, linguaggio accademico, istruzione esplicita 